Pacific Journal of Mathematics

A TOPOLOGICAL CHARACTERIZATION OF SETS OF REAL 


\title{
A TOPOLOGICAL CHARACTERIZATION OF SETS OF REAL NUMBERS
}

\author{
MARY ELLEN RUDiN
}

We will say that a space $E$ is of class $L$ if $E$ is a separable metric space which satisfies the following conditions:

(1) Each component of $E$ is a point or an arc (closed, open, or halfopen), and no interior point of an arc-component $A$ is a limit point of $E-A$.

(2) Each point of $E$ has arbitrarily small neighborhoods whose boundaries are finite sets.

The purpose of this note is to show that a necessary and sufficient condition that a space be homeomorphic to a set of real numbers is that it be of class $L$.

This gives an affirmative answer to a question raised by de Groot in $[1]$.

In [2] L. W. Cohen proved that a separable metric space is homeomorphic to a set of real numbers if and only if it satisfies (1) above and (3) and (4) below :

(3) $E$ is zero-dimensional at each of its point-components.

(4) If $p$ is an end point of an arc-component $A$, then the space $(E-A) \cup\{p\}$ is zero-dimensional at $p$.

Any set of real numbers is clearly of class $L$. To prove the converse it is sufficient to show that every space of class $L$ satisfies conditions (3) and (4). To this end it is clearly enough to show the following :

If $X$ is a component of the space $E$ of class $L$ and $\varepsilon$ is a positive number. there is a set $U(X, \varepsilon)$ which is both open and closed, contains $X$, and is contained in the union of $X$ with the $\varepsilon$-neighborhoods of its endpoints (if any).

Suppose $X$ is a component of a space $E$ of class $L$ and $\varepsilon$ is a positive number. There exists an open set $V$ which contains $X$ but contains no point whose distance from $X$ exceeds $\varepsilon$, such that the boundary $B$ of $V$ is finite; if $X$ is a point, we can apply (2) directly to obtain $V$; if $X$ is an arc, let $V$ consist of $X$ plus type (2) neighborhoods of the end points of $X$ (if any).

Let $G$ denote the sets of all points $p$ of $E$ such that $E$ is the union of two mutually separated sets $S_{p}$ and $T_{p}$, where $S_{p}$ contains $X$ and $T_{p}$ contains $p$.

Received May 22, 1956. Research supported by the National Science Foundation. 
Case I. $E-G=X$. Then $G$ contains $B$. Let $R$ be the union of all sets $T_{p}$ for $p$ in $B$. Since $B$ is finite, $R$ is both open and closed and $V-R$ is suitable for $U(X, \varepsilon)$.

Case II. $E-G \neq X$. Since $X$ is a component, $E-G$ is the union of two mutually separated sets $Y$ and $Z$, where $Y$ contains $X$ and $Z$ is not empty. It will be shown that there is a set $K$ which is both open and closed and contains $Z$ but does not intersect $X$, thus contradicting the fact that $Z$ is not in $G$.

The definition of $G$, together with the fact that $E$ has a countable base, implies that $G=\bigcup_{n=1}^{\infty} G_{n}$, where each $G_{n}$ is both open and closed.

Let $p$ be a point of $Z$. If $q$ is a point of $G$, then $T_{q}$ contains $q$ and not $p$. The reasoning used in Case I shows that there is a neighborhood $N_{p}$ of $p$ which has no boundary point in $G$ and whose diameter is less than half the distance from $p$ to $Y$.

Let $\left\{H_{n}\right\} \quad(n=1,2,3, \cdots)$ be a countable base for $E$. If $H_{n}$ is not a subset of $N_{p}$ for any $p$ in $Z$, put $K_{n}=0$. If, for some $p$ in $Z, H_{n}$ is a subset of $N_{p}$, let $N$ be one such $N_{p}$ and put $K_{n}=N-G_{n}$. Let $K=\bigcup_{n=1}^{\infty} K_{n}$. By the choice of $N_{p}, K$ has no limit point in $Y$. No $K_{n}$ has a boundary point in $G$ and only finitely many sets $K_{n}$ intersect any $G_{i}$. Consequently $K$ has no boundary points in $G$ and $K$ is both open and closed. Since $Z$ is a subset of $K$ and $X$ does not intersect $K$, the proof is complete.

\section{REFERENCES}

1. J. de Groot, On Cohen's topological characterization of sets of real numbers, Nederl. Akad. Wetensch. Proc. Ser. A, 58 (1955), 33-35.

2. L. W. Cohen, A characterization of those subsets of metric separable space which are homeomorphic with subsets of the linear continuum, Fund. Math. 14 (1929), 281-303. 


\section{PACIFIC JOURNAL OF MATHEMATICS}

\section{EDITORS}

H. L. ROYDEN

Stanford University

Stanford, California

R. A. Beaumont

University of Washington

Seattle 5, Washington

\section{A. L. Whiteman}

University of Southern California

Los Angeles 7, California

E. G. Straus

University of California

Los Angeles 24, California

\section{ASSOCIATE EDITORS}
E. F. BECKENBACH
C. E. BURGESS
M. HALL
E. HEWITT

\author{
A. HORN \\ V. GANAPATHY IYER \\ R. D. JAMES \\ M. S. KNEBELMAN
}

L. NACHBIN

I. NIVEN

G. SZEKERES

T. G. OSTROM

M. M. SCHIFFER
F. WOLF

K. YOSIDA

\section{SUPPORTING INSTITUTIONS}

\author{
UNIVERSITY OF BRITISH COLUMBIA \\ CALIFORNIA INSTITUTE OF TECHNOLOGY \\ UNIVERSITY OF CALIFORNIA \\ MONTANA STATE UNIVERSITY \\ UNIVERSITY OF NEVADA \\ OREGON STATE COLLEGE \\ UNIVERSITY OF OREGON \\ UNIVERSITY OF SOUTHERN CALIFORNIA
}

\author{
STANFORD UNIVERSITY \\ UNIVERSITY OF UTAH \\ WASHINGTON STATE COLLEGE \\ UNIVERSITY OF WASHINGTON \\ AMERICAN MATHEMATICAL SOCIETY \\ CALIFORNIA RESEARCH CORPORATION \\ HUGHES AIRCRAFT COMPANY \\ THE RAMO-WOOLDRIDGE CORPORATION
}

Mathematical papers intended for publication in the Pacific Journal of Mathematics should be typewritten (double spaced), and the author should keep a complete copy. Manuscripts may be sent to any of the editors. All other communications to the editors should be addressed to the managing editor, E. G. Straus at the University of California, Los Angeles 24, California.

50 reprints per author of each article are furnished free of charge; additional copies may be obtained at cost in multiples of 50 .

The Pacific Journal, of Mathematics is published quarterly, in March, June, September, and December. The price per volume (4 numbers) is $\$ 12.00$; single issues, $\$ 3.50$. Back numbers are available. Special price to individual faculty members of supporting institutions and to individual members of the American Mathematical Society: $\$ 4.00$ per volume; single issues, $\$ 1.25$.

Subscriptions, orders for back numbers, and changes of address should be sent to Pacific Journal of Mathematics, 2120 Oxford Street, Berkeley 4, California.

Printed at Kokusai Bunken Insatsusha (International Academic Printing Co., Ltd.), No. 10, 1-chome, Fujimi-cho, Chiyoda-ku, Tokyo, Japan.

PUBLISHED BY PACIFIC JOURNAL OF MATHEMATICS, A NON-PROFIT CORPORATION

The Supporting Institutions listed above contribute to the cost of publication of this Journal, but they are not owners or publishers and have no responsibility for its content or policies. 


\section{Pacific Journal of Mathematics}

\section{Vol. 7, No. 2 \\ February, 1957}

William F. Donoghue, Jr., The lattice of invariant subspaces of a completely continuous quasi-nilpotent transformation ................... 1031

Michael (Mihály) Fekete and J. L. Walsh, Asymptotic behavior of restricted extremal polynomials and of their zeros.................... 1037

Shaul Foguel, Biorthogonal systems in Banach spaces ............... 1065

David Gale, A theorem on flows in networks ................... 1073

Ioan M. James, On spaces with a multiplication .................. 1083

Richard Vincent Kadison and Isadore Manual Singer, Three test problems in operator theory .................................... 1101

Maurice Kennedy, A convergence theorem for a certain class of Markoff processes........................................ 1107

G. Kurepa, On a new reciprocity, distribution and duality law ........ 1125

Richard Kenneth Lashof, Lie algebras of locally compact groups ........ 1145

Calvin T. Long, Note on normal numbers .................... 1163

M. Mikolás, On certain sums generating the Dedekind sums and their reciprocity laws ..................................... 1167

Barrett O'Neill, Induced homology homomorphisms for set-valued maps......................................... 1179

Mary Ellen Rudin, A topological characterization of sets of real numbers........................................... 1185

M. Schiffer, The Fredholm eigen values of plane domains 1187

F. A. Valentine, A three point convexity property .........

Alexander Doniphan Wallace, The center of a compact lattice is totally

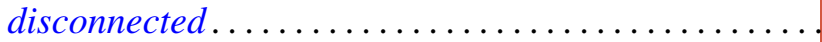

Alexander Doniphan Wallace, Two theorems on topological lattices.

G. T. Whyburn, Dimension and non-density preservation of mappings...

John Hunter Williamson, On the functional representation of certain algebraic systems ... 